\title{
A EDUCAÇÃO INCLUSIVA EM ESPAÇOS NÃO FORMAIS: UMA ANÁLISE DOS MUSEUS DE CIÊNCIAS BRASILEIROS
}

\author{
CLÁUDIA CELESTE SCHUINDT ${ }^{1}$ \\ ORCID: https://orcid.org/0000-0001-5112-2129 \\ CAMILA SILVEIRA ${ }^{2}$ \\ ORCID: https://orcid.org/0000-0003-0685-5897
}

\begin{abstract}
RESUMO: A presente pesquisa foi realizada a partir da articulação entre a Educação Inclusiva e o Ensino de Ciências em espaços não formais, buscando contribuir para que se ampliem as discussões no tocante à inclusão da pessoa com deficiência nos museus de Ciências incorporando ações de acessibilidade. Tendo como objetivo identificar e analisar as dimensões da Educação Inclusiva presentes/ausentes nos museus de Ciências brasileiros, foram investigadas as concepções dos coordenadores dos museus de Ciências e dos elaboradores do "Guia de Museus e Centros de Ciências Acessíveis" por meio de uma entrevista semiestruturada. Os dados foram analisados segundo a perspectiva da Análise de Conteúdo, segundo categorias definidas à priori. Observou-se que na dimensão Física há predominância dos aspectos pertinentes ao acesso à instituição. $\mathrm{Na}$ dimensão Programática foram identificadas ações que buscam diminuir as barreiras provenientes da falta de formação dos monitores, o que implica diretamente na mediação. Na dimensão Comunicacional foi possível identificar a criação de materiais táteis e manipuláveis. Na observação da dimensão Atitudinal, foi possível notar que as instituições têm desenvolvido práticas de sensibilização e de conscientização. Entretanto, os resultados mostram que algumas medidas ainda estão disponíveis com restrições, ou mesmo, indisponíveis. A implementação dessas mudanças deve ocorrer a curto, médio e longo prazo, visto que não é possível sanar definitivamente, todas as necessidades dos espaços e de seus visitantes. Ressaltamos a necessidade de que pesquisas futuras se dediquem a entender se a inclusão é realmente efetiva no espaço museal e como a pessoa com deficiência participa desse processo.
\end{abstract}

Palavras-chave: Inclusão, educação não formal, acessibilidade, museus de Ciências.

\section{INCLUSIVE EDUCATION IN NON-FORMAL SPACES: AN ANALYSIS OF BRAZILIAN SCIENCES MUSEUMS} \begin{abstract}
inclusion of people with disabilities in Science museums, incorporating accessibility actions. Aiming to identify and analyse the dimensions of Inclusive Education present / absent in Brazilian Science

\footnotetext{
${ }^{1}$ Universidade Federal do Paraná (UFPR). Curitiba, PR, Brasil. <claudiaschuindt.cs@gmail.com>

${ }^{2}$ Universidade Federal do Paraná (UFPR). Curitiba, PR, Brasil. <camila@quimica.ufpr.br>

ABSTRACT: This research was based on the articulation between Inclusive Education and Science Teaching in non-formal spaces, seeking to contribute to the expansion of discussions regarding the 
museums, the conceptions of the coordinators of Science museums and the creators of the "Guide to Accessible Science Museums and Science Centers" were investigated through a semi-structured interview. The data were analysed from the perspective of Content Analysis, according to categories defined a priori. Was observed that in the Physical dimension there is a predominance of aspects relevant to access to the institution. In the Programmatic dimension, actions that seek to reduce barriers arising from the lack of training of monitors were identified, which directly implies mediation. In the Communicational dimension, it was possible to identify the creation of tactile and manipulable materials. In observing the Attitudinal dimension it was noticed that the institutions have developed practices of sensitization and awareness. However, the results show that some measures are still available with restrictions, or even, unavailable. The implementation of these changes must occur in the short, medium and long term since it is not possible to definitively address all the needs of the spaces and their visitors. We emphasize the need for future research to be dedicated to understanding whether inclusion is effective in the museum space and how the disabled person participates in this process.

Keywords: Inclusion, non-formal education, accessibility, Science museums.

\section{EDUCACIÓN INCLUSIVA EN ESPACIOS INFORMALES: ANÁLISIS DE MUSEOS DE CIENCIAS BRASILEÑOS}

RESÚMEN: Esta investigación se llevó a cabo sobre la base de la articulación entre la Educación Inclusiva y la Enseñanza de la Ciencia en espacios no formales, buscando contribuir ampliar los debates sobre la inclusión de personas con discapacidad en los museos de Ciencias. Con el objetivo de identificar y analizar las dimensiones de la Educación Inclusiva presente/ausente en los museos de Ciencias brasileños, se investigaron las concepciones de los coordinadores de los museos de Ciencias y los elaboradores de lo " Guía de Museos y Centros de Ciencias Accesibles" mediante una entrevista semiestructurada. Los datos se analizaron de acuerdo con la perspectiva del Análisis de Contenido, según las categorías definidas a priori. Se observó que en la dimensión Física predominan los aspectos pertinentes al acceso a la institución. En la dimensión Programática, se identificaron acciones que buscan reducir las barreras resultantes de la falta de capacitación de los monitores. En la dimensión Comunicacional fue posible identificar la creación de materiales táctiles. Al observar la dimensión Actitudinal, fue posible notar que las instituciones han desarrollado prácticas de concienciación. Sin embargo, los resultados muestran que algunas medidas siguen estando disponibles con restricciones, o incluso no disponibles. La implantación de estos cambios debe producirse a corto, medio y largo plazo, ya que no es posible satisfacer definitivamente todas las necesidades de los espacios y sus visitantes. Hacemos hincapié en la necesidad de que la investigación futura entienda si la inclusión es efectiva y cómo la persona discapacitada participa en este proceso.

Palabras clave: Inclusión, educación no formal, accesibilidad, museos de Ciencia. 


\section{ACESSIBILIDADE E INCLUSÃO NOS MUSEUS DE CIÊNCIAS}

Esta pesquisa tem como cenário a intersecção entre a Educação Inclusiva e o Ensino de Ciências em espaços não formais e busca contribuir para que se ampliem as discussões no que diz respeito à inclusão de pessoa com deficiência nos museus de Ciências.

Quando entendemos que não é o estreitamento e a universalidade da espécie que definem um sujeito, mas sim, as suas particularidades, suas singularidades, percebemos que tratar as pessoas desigualmente enfatiza suas diferenças, assim como tratá-las exatamente da mesma maneira esconde as suas especificidades e as excluí do mesmo modo.

Assim, não é suficiente tratar o indivíduo de forma genérica, geral e abstrata, é necessário avaliar suas necessidades e a melhor forma de adaptar o espaço para que possa atendê-lo, visto que, a deficiência, não é mais entendida como uma condição estática e biológica da pessoa, mas sim, como o resultado da interação das barreiras impostas pelo meio com as limitações de natureza física, mental, intelectual e sensorial do indivíduo (BRASIL, 2015).

Os museus de Ciências são espaços não formais de educação que contribuem para a formação cultural e científica das pessoas. Além de proporcionarem lazer em um ambiente educativo, pois, promovem a construção e desenvolvimento cultural da sociedade, tendo de estar disponíveis para todo o tipo de público (CAZELLI; MARANDINO; STUDART, 2003; NORBERTO ROCHA; MARANDINO, 2017; CERATI, 2014; OLIVEIRA, 2013).

Mendes Braga (2017) declara que a função pedagógica dos museus tem sido fortalecida por meio das experiências e investigações desenvolvidas nesses espaços científico-culturais, e evidenciada pelo poder de comunicação que possuem. Como consequência, o público tem abandonado seu posicionamento de mero espectador passivo, assumindo o papel de protagonista. Entretanto, entendemos que para que o público com deficiência assuma esse lugar, os museus devem garantir que, além do acesso ao local, os aspectos da inclusão sejam respeitados, sejam eles o direito à acessibilidade, a igualdade de oportunidades, a fruição de maneira segura, independente e autônoma, por exemplo.

A acessibilidade, quando tratada de modo amplo, extrapolando os aspectos físicos e espaciais faz parte dos problemas estruturais da sociedade. A democratização e o acesso aos bens culturais vêm passando por sistemáticos processos de criação e reestruturação nos pontos de vista conceitual, político e social.

As políticas de acessibilidade museal passaram a ser discutidas apenas a partir de 2009, com a criação do Plano Nacional Setorial de Museus (PNSM) (BRASIL, 2010). Esse documento trata a acessibilidade de maneira articulada com a sustentabilidade ambiental e propõe que o ambiente dos museus seja adequado de maneira a garantir práticas de acessibilidade universal. Essas diretrizes têm como meta garantir que medidas de acessibilidade façam parte das ações tomadas pelos gestores das instituições.

Segundo a Política Nacional de Educação Museal (BRASIL, 2018), os museus devem buscar a "acessibilidade plena", ou seja, buscar a superação das diversas barreiras que dificultam ou impedem o acesso. É imprescindível que a organização desses espaços atenda às necessidades de todos os seus usuários, que sejam pensados e desenvolvidos projetos que garantam o respeito e a plena fruição para todos.

Com os avanços da Legislação e dos documentos legais em defesa dos direitos das pessoas com deficiência, a acessibilidade ganhou, gradualmente, mais espaço na agenda de estudos em museus, espaços científico-culturais, ações de divulgação da Ciência e nas discussões entre pesquisadores, professores e profissionais da área (TOJAL, 1999; TOJAL, 2007; SARRAF, 2008; CARDINALI, 2008; SARRAF, 2013; MOLENZANI e NORBERTO ROCHA, 2017; MASSARANI et al., 2017).

Entende-se, então, a importância de discutir como a acessibilidade e a inclusão se articulam nos Museus de Ciências. A inclusão nesses espaços só consegue atingir seu objetivo se identificarmos como a acessibilidade está ou não presente nesses locais possibilitando e favorecendo a autonomia do visitante com deficiência.

Os princípios da inclusão são pautados em valores éticos que preconizam a celebração das diferenças, a igualdade, a valorização da diversidade, o aprendizado cooperativo, a solidariedade, a 
igualdade de classes e o direito de todos terem uma vida digna, com qualidade em todos os aspectos como lazer, cultura, trabalho e educação.

A inclusão envolve tanto a acessibilidade, quanto à quebra de barreiras e está vinculada à cultura na qual não há um olhar de diferenciação.

De acordo com Sassaki:

Inclusão, como um paradigma de sociedade, é o processo pelo qual os sistemas sociais comuns são tornados adequados para toda a diversidade humana - composta por etnia, raça, língua, nacionalidade, gênero, orientação sexual, deficiência e outros atributos - com a participação das próprias pessoas na formulação e execução dessas adequações (SASSAKI, 2009, p. 10).

Para garantir a concretização dos direitos da pessoa com deficiência é preciso reconhecer sua identidade própria e prover os recursos necessários para possibilitar sua plena e efetiva participação na sociedade, em igualdade de condições com as demais pessoas.

Destacamos que no cenário atual onde se busca uma sociedade inclusiva, faz-se necessária a busca de recursos que visem incluir e não simplesmente inserir a pessoa nos ambientes destinados à sua educação, saúde, lazer e trabalho (CARDINALI, 2008). Percebe-se que a inclusão é fundamental para a construção de uma sociedade democrática. O respeito às diferenças e a igualdade de oportunidades requer o movimento de incluir, ou seja, uma ruptura com o movimento da exclusão. Ele é a garantia do acesso contínuo ao espaço comum na vida em sociedade, que deverá estar organizada e orientada, respeitando a diversidade humana, as diferenças individuais, promovendo igualdade de oportunidades de desenvolvimento para toda a vida (MARQUES; MARQUES, 2006).

Assim, concordando com Rodrigues (2012), considera-se que para assegurar que esse direito esteja sendo exercido, é obrigatória a reflexão, não somente sobre as condições de acesso, mas, também, sobre as condições de sucesso que ele é capaz de proporcionar. Desta forma, não se pode pensar numa educação em museus sem levar em conta essa especificidade, que irá determinar uma forma particular de educação.

A acessibilidade, nesse sentido, vai além do físico, ultrapassa a eliminação de barreiras arquitetônicas e adiciona outros aspectos de caráter comunicacional, atitudinal, cognitivo e social. Cohen, Duarte e Brasileiro (2012, p. 2) argumentam em favor da "acessibilidade plena", considerando a abordagem multissensorial que abrange as várias deficiências e significa considerar a acessibilidade além de sua vertente física.

Nessa perspectiva, acreditamos que a discussão sobre acessibilidade é muito ampla e passa, principalmente, pela questão da inclusão. A inclusão implica na transformação da cultura, das práticas e das políticas vigentes, de modo a garantir o acesso, a participação e a aprendizagem de todos, sem exceção, independentemente de suas condições, pois, pressupõe a igualdade de oportunidades e a valorização das diferenças. Sobretudo, é fundamental que a inclusão não tenha um caráter filantrópico e assistencialista.

Sassaki (2009), afirma que a sociedade é que precisa ser modificada, devendo ser capaz de atender às necessidades de seus membros, tendo esses como parceiros na discussão de problemas e soluções. O autor divide o conceito de acessibilidade em seis dimensões: "arquitetônica, comunicacional, metodológica, instrumental, programática e atitudinal, mostrando que todas essas dimensões são importantes, se faltar uma, compromete as outras" (SASSAKI, 2005, p. 22).

Entendemos que para que a inclusão ocorra de forma efetiva é preciso superar as barreiras da acessibilidade. Apontamos, então, quais são as principais:

Acessibilidade arquitetônica: está relacionada com a superação das barreiras estruturais e físicas nos espaços e em seu entorno. As barreiras arquitetônicas prejudicam a circulação e fruição no espaço museológico não só por parte da pessoa com deficiência física ou mobilidade reduzida, mas também por parte dos demais visitantes, crianças e idosos, por exemplo (TOJAL, 2007).

Acessibilidade programática ou institucional: busca eliminar barreiras invisíveis embutidas em políticas públicas, Leis, Decretos, Portarias, resoluções, medidas provisórias e enfatiza a necessidade de se haver políticas institucionais para a promoção da acessibilidade. 
Acessibilidade comunicacional: voltada a eliminar as barreiras de comunicação interpessoal, visual e escrita - língua de sinais, linguagem corporal, linguagem textual, textos em Braille, textos com letras ampliadas para quem tem baixa visão, e tecnologias assistivas para comunicação virtual, incluindo recursos de acessibilidade multissensoriais contextualizados na exposição.

Acessibilidade atitudinal: programas e práticas de sensibilização e de conscientização das pessoas em geral e da convivência na diversidade humana resultando na quebra de preconceitos, estigmas, estereótipos e discriminações. Desconstruindo da imagem negativa vinculada à pessoa com deficiência, que muitas vezes leva a atitudes de discriminação, e assegurando a dignidade e o respeito pela diferença (TOJAL, 2015). Desta forma, entendemos que é missão da instituição programar as ações educativas inclusivas, divulgar suas atividades, elaborar materiais de apoio, conscientizar e formar profissionais, acompanhar o atendimento ao público e aperfeiçoar os recursos humanos existentes.

O modelo social destaca o impacto do ambiente na vida da pessoa com deficiência e enfatiza que as barreiras arquitetônicas, de comunicação e atitudinais existentes devem ser removidas para possibilitar a inclusão, e novas devem ser evitadas ou impedidas, com o intuito de deixar de gerar exclusão (SASSAKI, 2009).

As práticas devem ser baseadas na valorização da diversidade humana, no respeito pelas diferenças individuais, no acolhimento de todas as pessoas e na participação ativa da comunidade em todas as etapas do processo de inclusão. Felizmente, a inclusão é um processo irreversível, uma vez que veio para abrir caminhos e construir uma sociedade verdadeiramente para todos, sem exceção, sob nenhuma hipótese.

Assim, o objetivo desse trabalho é discutir e analisar quais as dimensões da Educação Inclusiva presentes/ausentes nos museus de Ciências brasileiros. Para isso mapearemos os Museus de Ciências Acessíveis no Brasil, identificando as dimensões da Educação Inclusiva nas instituições, investigando as concepções dos coordenadores dos Museus de Ciências e dos elaboradores do "Guia de Museus e Centros de Ciências Acessíveis" (NORBERTO ROCHA et al., 2017) e analisando as práticas inclusivas dos espaços museais investigados.

\section{CAMINHOS METODOLÓGICOS}

Essa pesquisa é de natureza qualitativa que pode ser caracterizada por possuir aspectos essenciais que consistem na escolha adequada de métodos e teorias convenientes aos objetivos da pesquisa, reconhecimento e análise de diferentes perspectivas, não se restringindo à apenas uma metodologia (FLICK, 2008).

Os procedimentos metodológicos adotados seguem os pressupostos da pesquisa hermenêutica fenomenológica (DIT'TRICH; LEOPARDI, 2015) que busca uma maneira de entender e expressar a percepção sobre os acontecimentos, tendo como ponto de partida a realidade social dos sujeitos e seu objetivo é a sua compreensão das vivências, procurando compreender o meio e, o que ele significa para os indivíduos, bem como quais implicações ele traz.

A fim de atender aos objetivos da pesquisa proposta, fez-se necessário um levantamento dos dados a respeito da acessibilidade e inclusão nos museus de Ciências, para tal, utilizou-se os procedimentos da Análise Documental, que permitem ao pesquisador a cobertura de uma gama de observações muito mais ampla, possibilitando uma maior quantidade de interpretações (GIL, 2008). O objeto de análise nessa etapa foi o "Guia de Museus e Centro de Ciências Acessíveis da América Latina e Caribe" (NORBERTO ROCHA et al., 2017), para tal, foram estabelecidas categorias a priori visando sistematizar o processo de leitura, interpretação e identificação de informações constantes no Guia. As categorias previamente definidas foram: a) localização da instituição; b) tipos de acessibilidade; e c) temas das exposições.

Ao analisar todo o Guia, segundo os critérios previamente estabelecidos, foram localizados 69 museus de Ciências acessíveis em território brasileiro, distribuídos nas cinco regiões do país, dentre os 110 constantes na América Latina e Caribe. Após a análise das instituições presentes no Guia, os resultados foram agrupados com o propósito de traçar o panorama nacional. 
A fim de identificar os participantes da pesquisa, selecionamos um museu de Ciências por região, para tal escolha foram atribuídos alguns critérios: um por região do Brasil, com sede fixa, ou seja, não itinerante, com o maior número de itens de acessibilidade e os temas de suas exposições deveriam abranger mais áreas de conhecimento. A busca dessas informações se deu nos sítios da internet, no Guia de Museus e Centros de Ciências Acessíveis da América Latina (NORBERTO ROCHA et al., 2017) e em informações disponíveis nos sites das instituições.

Buscando localizar as instituições participantes, cruzando os parâmetros estabelecidos como direcionamento para a escolha de cada espaço listaremos a seguir as instituições participantes dessa pesquisa (QUADRO 1).

QUADRO 1 - Instituições participantes da pesquisa

\begin{tabular}{|c|c|c|c|c|}
\hline $\begin{array}{l}\text { NOME DA } \\
\text { INSTITUIÇÃO }\end{array}$ & LOCALIZAÇÃO & $\begin{array}{c}\text { ANO DE } \\
\text { INAUGURAÇÃO }\end{array}$ & $\begin{array}{c}\text { ÁREAS DE } \\
\text { CONHECIMENTO } \\
\text { DAS EXPOSIÇÕES }\end{array}$ & $\begin{array}{l}\text { MEDIDAS DE } \\
\text { ACESSIBILIDADE } \\
\text { PRESENTES }\end{array}$ \\
\hline $\begin{array}{l}\text { Casa da Ciência e } \\
\text { Cultura de } \\
\text { Campo Grande }\end{array}$ & $\begin{array}{c}\text { Campo Grande - } \\
\text { MS } \\
\text { Região Centro- } \\
\text { Oeste }\end{array}$ & 2007 & $\begin{array}{c}\text { Química, à Biologia e à } \\
\text { Astronomia }\end{array}$ & $\begin{array}{l}\text { Acessibilidade física; } \\
\text { materiais manipuláveis; } \\
\text { audiodescrição em } \\
\text { português. }\end{array}$ \\
\hline $\begin{array}{l}\text { Laboratório de } \\
\text { Divulgação } \\
\text { Científica Ilha da } \\
\text { Ciência }\end{array}$ & $\begin{array}{l}\text { São Luís do } \\
\text { Maranhão - MA } \\
\text { Região Nordeste }\end{array}$ & 1992 & $\begin{array}{l}\text { Astronomia, Física, } \\
\text { Matemática e Química. }\end{array}$ & $\begin{array}{l}\text { Acessibilidade física; } \\
\text { materiais manipuláveis; } \\
\text { computadores com } \\
\text { softwares sintetizadores de } \\
\text { voz; guia vidente e } \\
\text { intérprete de LIBRAS; } \\
\text { materiais com tradução } \\
\text { em LIBRAS. }\end{array}$ \\
\hline $\begin{array}{l}\text { Centro de } \\
\text { Ciências e } \\
\text { Planetário do } \\
\text { Pará }\end{array}$ & $\begin{array}{l}\text { Belém - Pará } \\
\text { Região Norte }\end{array}$ & 2012 & $\begin{array}{c}\text { Astronomia, Biologia, } \\
\text { Ciências, Física, } \\
\text { Geologia, Matemática e } \\
\text { Química }\end{array}$ & $\begin{array}{c}\text { Acessibilidade física; } \\
\text { audiodescrição em } \\
\text { português, experimentos } \\
\text { manipuláveis; guia vidente. }\end{array}$ \\
\hline $\begin{array}{l}\text { Centro de } \\
\text { Divulgação } \\
\text { Científica e } \\
\text { Cultural da } \\
\text { Universidade de } \\
\text { São Paulo }\end{array}$ & $\begin{array}{l}\text { São Carlos - SP } \\
\text { Região Sudeste }\end{array}$ & 1980 & $\begin{array}{c}\text { Química, Física, } \\
\text { Matemática, Biologia, } \\
\text { Educação Ambiental e } \\
\text { Astronomia }\end{array}$ & $\begin{array}{l}\text { Acessibilidade física; } \\
\text { experimentos interativos } \\
\text { em altura acessível; } \\
\text { audiodescrição em } \\
\text { português; softwares } \\
\text { sintetizadores de voz. }\end{array}$ \\
\hline $\begin{array}{l}\text { Museu Dinâmico } \\
\text { Interdisciplinar }\end{array}$ & $\begin{array}{l}\text { Maringá - PR } \\
\text { Região Sul }\end{array}$ & 1985 & $\begin{array}{c}\text { Biologia, Física e } \\
\text { Química }\end{array}$ & $\begin{array}{c}\text { Acessibilidade física; } \\
\text { painéis em Braille, } \\
\text { experimentos } \\
\text { manipuláveis; materiais } \\
\text { com audiodescrição em } \\
\text { português. }\end{array}$ \\
\hline
\end{tabular}

Fonte: As autoras (2020).

Após a seleção das instituições por região foi realizada uma entrevista semiestruturada, que foi gravada em áudio e posteriormente transcrita, com um coordenador e/ou diretor, com o objetivo identificar quais são os indicadores de inclusão presentes/ausentes nesses espaços. As entrevistas foram realizadas pessoalmente e/ou via Skype ${ }^{\circledR}$, gravadas e transcritas como apresentado no Quadro 2.

QUADRO 2 - Descrição dos participantes entrevistados e duração da entrevista

\begin{tabular}{|c|c|c|c|}
\hline INSTITUIÇÃO & PARTICIPANTE & ATUAÇÃO & $\begin{array}{c}\text { TEMPO NA } \\
\text { INSTITUIÇÃO }\end{array}$ \\
\hline $\begin{array}{c}\text { Casa de Ciência e Cultura de } \\
\text { Campo Grande }\end{array}$ & Iasmin & $\begin{array}{c}\text { Professora e } \\
\text { pesquisadora }\end{array}$ & 11 anos \\
\hline
\end{tabular}




\begin{tabular}{|c|c|c|c|}
\hline $\begin{array}{l}\text { Laboratório de Divulgação } \\
\text { Científica Ilha da Ciência }\end{array}$ & Osvaldo & $\begin{array}{l}\text { Professor e } \\
\text { pesquisador }\end{array}$ & 26 anos \\
\hline $\begin{array}{l}\text { Centro de Ciências e } \\
\text { Planetário do Pará }\end{array}$ & Silmara & $\begin{array}{l}\text { Professora e } \\
\text { pesquisadora }\end{array}$ & 8 anos \\
\hline $\begin{array}{c}\text { Centro de Divulgação } \\
\text { Científica e Cultural (CDCC) }\end{array}$ & Andreia & $\begin{array}{l}\text { Curadora e } \\
\text { bibliotecária }\end{array}$ & 13 anos \\
\hline $\begin{array}{c}\text { Museu Dinâmico } \\
\text { Interdisciplinar (MUDI) }\end{array}$ & Amanda & $\begin{array}{l}\text { Professora e } \\
\text { pesquisadora }\end{array}$ & 15 anos \\
\hline $\begin{array}{c}\text { Grupo Museus e Centro de } \\
\text { Ciências Acessíveis }\end{array}$ & Júlia & $\begin{array}{l}\text { Professora e } \\
\text { pesquisadora }\end{array}$ & 3 anos \\
\hline
\end{tabular}

Fonte: As autoras (2020)

Após a seleção das instituições foi realizada uma entrevista semiestruturada com os diretores/coordenadores de cada museu, que teve por objetivo reconhecer nas falas a presença/ausência da acessibilidade nos museus de Ciências e interpretar como foi o processo de concepção e execução dessas medidas. O roteiro de entrevista continha questões que versavam sobre inclusão e/ou acessibilidade nas exposições, implementação das medidas de acessibilidade, participação da pessoa com deficiência nesse processo, mediação e como as medidas de acessibilidade se articulam com a inclusão.

A reunião desses dados foi analisada segundo a perspectiva da Análise de Conteúdo de Bardin (2016), tendo como unidade de registro o tema, e para tanto os dados produzidos nas entrevistas foram categorizados a fim de que os resultados fossem dispostos de maneira que os aspectos semelhantes entre os espaços estudados pudessem revelar quais são as dimensões da Educação Inclusiva presentes/ausentes nos Museus de Ciências brasileiros. Deste modo, quatro grandes categorias foram definidas a priori e nortearam o agrupamento das informações para posterior diálogo com as bases teóricas:

a) Acessibilidade arquitetônica/física: observou-se nessa categoria os aspectos que abrangem a acessibilidade física local e do entorno da instituição, isso é, desde a chegada do público ao local, até a sua recepção e acomodação.

b) Acessibilidade programática/institucional: observamos quais políticas e medidas os coordenadores/diretores estão buscando implantar para eliminar barreiras institucionais para a promoção da acessibilidade.

c) Acessibilidade comunicacional: essa categoria foi observada por meio da existência/inexistência de equipamentos e recursos que permitam a superação das barreiras comunicacionais, de escrita e/ou de informação, por meio da utilização de leitores de tela; tamanho da fonte; alternativas de idioma, por exemplo, LIBRAS ou BRAILLE; recursos táteis de apoio bi e/ou tridimensionais, recursos multissensoriais.

d) Acessibilidade atitudinal: nessa categoria foram observadas as atitudes, ações de formação, voltadas a eliminar os preconceitos, estereótipos e estigmas existentes entre as pessoas, tanto pelos funcionários quanto pelos visitantes, como também promover a inclusão profissional da pessoa com deficiência, e parcerias com instituições e/ou organizações dirigidas à pessoa com deficiência.

Posteriormente, foram realizadas as interpretações e análises dos resultados, procurando desvelar quais são as dimensões da Educação Inclusiva presentes/ausentes nos museus de Ciências brasileiros. 


\section{RESULTADOS E DISCUSSÃO}

Dada à especificidade, importância deste tema e a escassez de investigações na Área de Ensino de Ciências que tomam como objeto de estudos esses espaços (MASSARANI et al., 2017), buscou-se mapear os Museus de Ciências Acessíveis brasileiros bem como as áreas de conhecimento abarcadas em suas exposições na perspectiva da Educação e Divulgação Científica Inclusiva e os tipos de acessibilidade em cada um deles a partir do "Guia de Museus e Centro de Ciências Acessíveis" (NORBERTO ROCHA et al., 2017) com o propósito de identificar os participantes da pesquisa.

Para tal, fez-se necessário traçar um panorama geral dos museus de Ciências no Brasil. Conforme informações do Guia (NORBERTO ROCHA et al., 2017), existem 69 instituições acessíveis em território brasileiro, que estão distribuídas da seguinte forma: três estão alocados na região CentroOeste, 14 na região Nordeste, 11 na região Norte, 37 estão na região Sudeste e por fim, 11 na região Sul.

Os dados mostraram que todas as regiões estão representadas, porém não são todos os Estados do país que têm museus de Ciências Acessíveis (MCA), nestes encontram-se os Estados do Acre, Amapá, Espírito Santo, Mato Grosso, Rondônia, Roraima, Sergipe e Tocantins, inviabilizando a visitação do público com deficiência nesses territórios.

Observa-se que a quantidade de instituições acessíveis ainda é pequena comparado às 268 distribuídas em território nacional (ABCMC, 2015), apenas cerca de 26\% dos museus de Ciências são acessíveis, o que está em desacordo com as Leis que garantem o acesso e permanência de todas as pessoas independentemente de sua condição física, intelectual e/ou social a esses espaços (BRASIL, 2015; BRASIL, 2018) e vai contra ao que está previsto no PNSM (BRASIL, 2010).

Quanto às áreas de conhecimento das exposições, há predominância dos conteúdos pertinentes à Biologia (43 MCA), seguido dos conteúdos de Astronomia (30 MCA) o que pode ser justificado pela grande quantidade de Zoológicos e Planetários. As exposições que abordam temáticas pertencentes à Física totalizam 25, enquanto, 19 à Química, 15 à História e 13 à Matemática, 12 às Ciências da Natureza. É possível, ainda, observar seis instituições que trabalham temáticas relacionadas à Geografia e/ou à Antropologia, três à Arqueologia, duas à Arte e à Música, uma à Filosofia e três não puderam ter os conteúdos identificados, pois seus sites estavam inativos ou o conteúdo das exposições não pode ser localizado. Esses resultados se baseiam nas informações disponibilizadas nos sites das instituições.

As exposições contêm elementos fundamentais próprios da identidade de cada museu. $\mathrm{O}$ conhecimento científico inerente a cada uma delas transita desde a formulação de teorias, metodologias até as práticas sobre como se darão as exibições a fim de que sua integridade seja mantida e o espaço seja capaz de promover uma reflexão científica (MARANDINO, 2002). A autora enfatiza que a temática das exposições possui um papel social que se estende para além da coleta, preservação e exposição de objetos, pois, tem múltiplos propósitos e múltiplas dimensões e oferecem maneiras agradáveis de aprendizagem, além, de proporcionarem entretenimento, e é por meio da mesma que se dá a missão educacional dos museus, o que implica na importância de estudar como ela está acontecendo nesses locais.

Segundo Tojal (2015) o aumento da procura aos museus de Ciências pelo público com deficiência se deu a partir de um processo longo e delicado de abertura e adequação dessas instituições que, "eram inicialmente dedicadas a uma finalidade mais restrita e elitizada" (p. 192), e, passam a ser alvo de diferentes classes e público variado, o que lhes confere um papel incisivo na transformação do conhecimento científico, na ruptura do paradigma de que o espaço museal se restringe ao invés de se ampliar, tornando-se cada vez mais acessíveis e inclusivos para todos.

Entretanto, é imprescindível que o conteúdo desses espaços não banalize os conteúdos científicos e tecnológicos a partir do reducionismo e exibicionismo dos mesmos. É fundamental que esses locais possibilitem aos cidadãos discutirem livremente sobre seus conteúdos e possam entender quais são as implicações da Ciência em seu cotidiano, criando a ideia de responsabilidade social (JACOBUCCI, 2008).

Para tanto, fez-se necessário que medidas que favorecessem a acessibilidade fossem adotadas, tornando esses espaços locais capazes de receber o público com deficiência, e desta maneira, buscamos identificar quais itens de acessibilidade estão presentes nos museus de Ciências Acessíveis a partir das 
informações presentes no Guia (NORBERTO ROCHA et al., 2017) e notou-se que há um predomínio da acessibilidade física (67 MCA) e um número expressivo de museus que possuem acessibilidade visual (63 MCA).

É possível observar que as medidas de Acessibilidade Física são predominantes, pois, normalmente estão relacionadas às mudanças estruturais e arquitetônicas, entretanto, Tojal (2007) aponta que essas medidas não são suficientes se oferecidas de forma descontextualizada. Em sequência, percebese que ações de Acessibilidade Visual e Auditiva (41 MCA) são mais marcantes em relação às demais, e isso se justifica pela elaboração de audiodescrição das exposições e a criação de materiais táteis, o que tem tornado o museu um espaço mais interativo, em contrapartida à visão essencialmente expositiva antes vista (TOJAL, 2015).

Tal preposição, explicita a importância de se ampliar o acesso aos MCA, de não limitar a acessibilidade somente à eliminação de barreiras arquitetônicas, a deficiências visuais, auditivas ou para pessoas com mobilidade reduzida. É imprescindível que todos os públicos se sintam amplamente incluídos nesses espaços e que possam usufruir todas as suas funcionalidades de maneira igualitária, entretanto, somente a acessibilidade não garante que esse processo de inclusão ocorra efetivamente.

Para que os MCA se tornem espaços acolhedores de todos os seus visitantes faz-se necessário transformar suas intenções em ações, de modo que a inclusão ocorra efetivamente. Esses dados vão ao encontro da pesquisa realizada por Tojal (2015) que evidencia que nenhuma estratégia de mediação, entre o objeto cultural e o público com deficiência, será eficaz se não vier acompanhada de um conceito de acessibilidade comunicacional e atitudinal em todas as instâncias museológicas e culturais dessas instituições.

A inclusão garante a todos o direito de participar das mais variadas esferas sociais e educativas, um local onde sejam possíveis o acesso e a permanência de todos, e onde os mecanismos de seleção e discriminação sejam substituídos por procedimentos de identificação e remoção de barreiras, não somente arquitetônicas, mas de aprendizagem.

Dessa maneira, após a reunião dos dados e a seleção das instituições participantes, segundo os critérios previamente estabelecidos, foram realizadas as entrevistas, cujas falas foram categorizadas a fim de que os resultados fossem dispostos de maneira que os aspectos semelhantes entre os espaços estudados pudessem desvelar quais são as dimensões da Educação Inclusiva presentes/ausentes nos Museus de Ciências brasileiros, que serão discutidas a seguir.

Dentro da categoria Acessibilidade Física observamos os aspectos da acessibilidade no local e no entorno da instituição, isso é, o acesso à instituição, existência de uma entrada comum e acessível a todos os visitantes, piso tátil nas áreas externas e/ou internas, bebedouros e sanitários acessíveis às pessoas em cadeiras de rodas, de baixa estatura e/ou com mobilidade reduzida, equipamentos em altura apropriada para pessoas em cadeiras de rodas ou de baixa estatura, mapa tátil e audiodescrição do espaço museológico.

Buscamos cruzar as informações autodeclaradas presentes no "Guia de Museus e Centro de Ciências Acessíveis" (NORBERTO ROCHA, et al., 2017) e as falas dos entrevistados para entender como a acessibilidade física e arquitetônica têm sido entendida e de que forma ela está presente nesses espaços.

Segundo informação constante no Guia (NORBERTO ROCHA, et al., 2017), os museus possuem entradas e saídas em nível e/ou possuem rampas de acesso e/ou equipamentos eletromecânicos.

Entretanto, durante a entrevista constata-se que os locais são parcialmente adaptados, e não dispõe de uma estrutura adequada para receber o visitante, conforme excerto a seguir:

Bom, era pra ter uma rampa de acesso, né? Pra cadeirante que não... não foi feita, então o... o acesso é assim, é parcialmente adequado porque a pessoa tem que... se vier, né? Se chegar de carro ótimo, tem as rampas tudo, né? Mas se não, se chegar de ônibus, por exemplo, ai ela tem que passar pelo asfalto e tal, não é... como eu disse, é parcialmente acessivel, né? (Iasmin).

Ressaltamos a importância de os Museus deixarem de ser espaços elitizados, concordando com Marandino (2005) quando essa afirma que é imprescindível que ocorram os processos de apropriação cultural e a socialização dos saberes, independente da classe social de seus visitantes e que 
passem a coexistir como um território de representação dos grupos socialmente excluídos e isso implica diretamente nas condições de locomoção dos visitantes.

Os espaços museais ainda possuem muitas barreiras físicas e arquitetônicas. Em suma, elas prejudicam o acesso às instituições, Inácio (2017) as chama de impedimentos de "circulação vertical", pois, prejudicam ou impossibilitam que as pessoas com dificuldade de locomoção acessem os ambientes.

Segundo Cohen, Duarte e Brasileiro (2012) visitar um museu é mais do que ter acesso à parte interna da instituição, é poder percorrer os espaços e ao mesmo tempo conquistar esses lugares, apropriar-se e se identificar. Segundo as autoras tanto nas rotas para se chegar ao museu, quanto no seu acesso imediato e em suas áreas internas, devem haver pisos com sinalização tátil com duas funções básicas: a de guiar e a de alertar - "piso guia e piso de alerta" (ABNT, 2015, p. 48).

Ações de acessibilidade são fundamentais para que a inclusão aconteça, entretanto, quando surgem de maneira isolada e pontual não garantem que o visitante seja incluído no espaço (TOJAL, 2005). Sassaki (2009) afirma que a inclusão é um processo e inúmeros são os fatores necessários para que ela seja real, dentre eles, a acessibilidade, seja ela física, de entorno, auditiva e ou visual.

Entretanto, dificuldades no acesso não são os únicos impedimentos presentes nos museus, segundo a entrevistada Silmara:

O acesso da pessoa com deficiência... a cúpula, ela não foi originalmente projetada pra isso, né? Então, geralmente, quando vinha alguém, não tem um lugar especifico, por exemplo, pra encaixar a cadeira do cadeirante, né? Então, ele fica meio que ali onde seria o caminho, que quando fecha a sala deixa de ser, mas é uma coisa, assim, improvisada (Silmara).

Conseguir entrar fisicamente em um museu não é garantia da compreensão das exposições, assim como participar de uma atividade não é garantia de sentir-se à vontade no museu, nem pertencente a esse universo cultural (AIDAR, 2002), já que inserir não é sinônimo de incluir. A eliminação das barreiras é fundamental e tem influência direta nos processos educativos, posto que o bem-estar, ou malestar nesse espaço impacta diretamente os processos de aprendizagem.

Assim, é necessário estar pronto a atender todo e qualquer tipo de necessidade que o visitante venha possuir, garantindo a possibilidade e condição de alcance, percepção e entendimento, em igualdade com os demais. A entrevistada declara que:

Então, uma das coisas que a gente descobriu, né? É que a rampa de acesso, o acesso ao cadeirante, né? Ele não pode ser a parte, pela mesma entrada que entra o visitante, os demais visitantes, entraria o cadeirante. Então, por exemplo, a rampa de acesso ao cadeirante que a gente tem aqui, ela é numa entrada diferente, né? Mas ela já foi desde a construção (Silmara).

Percebemos na fala de Silmara, que já há a conscientização de que as medidas de acessibilidade não devem fazer diferenciação entre os visitantes, a inclusão diz respeito à totalidade, e não a medidas isoladas, pontuais ou excludentes.

Segundo o princípio do uso equitativo presente na NBR 9050 (ABNT, 2015), os espaços devem possibilitar e oportunizar uso contínuo e igualitário para todos os visitantes, independentemente de sua condição, de forma idêntica, evitando a segregação dos usuários. O acesso por entradas secundárias só deve ser feito quando esgotadas todas as possibilidades de adequação da entrada principal, ou seja, a entrada predial principal tem a obrigatoriedade de atender a todas as pessoas.

Segundo Sassaki,

A inclusão é o processo pelo qual a sociedade e o portador de deficiência procuram adaptar-se mutuamente tendo em vista a equiparação de oportunidades e, consequentemente, uma sociedade para todos. A inclusão significa que a sociedade deve adaptar-se às necessidades da pessoa com deficiência para que esta possa desenvolver-se em todos os aspectos da sua vida. (SASSAKI, 2009, p. 5).

Entendemos que as barreiras arquitetônicas além de impedirem a circulação livre e espontânea, podem causar desconforto e constrangimentos.

Segundo a entrevistada Andreia, 
O jardim, ele é já especifico para receber essas pessoas [...] um cadeirante pode visitar sozinho o espaço, né? Ele não é totalmente autônomo pra visita, mas ele oferece condições para a pessoa visitar (Andreia).

Ao chegar ao museu os visitantes carregam consigo expectativas em relação ao que vão encontrar e à forma como irão interagir com todo o contexto que os rodeia, segundo Aidar (2002) nessas experiências estão incutidos os contextos pessoais, sociais e culturais em relação às características físicas do museu, o que poderão fazer, ver e encontrar e a maneira como isso acontecerá. Destaca-se, portanto, a importância de tornar esse processo, cada vez mais emancipatório.

A entrevistada Júlia ressalta que,

É muito difícil ter uma acessibilidade total, mas a gente com conjugação de estratégias e boa vontade, a gente pelo menos a barreira humana, a gente consegue vencer. Agora, barreiras de edifícios dependem de infraestrutura, barreiras financeiras dependem de um trabalho mais complicado, né? [...] 'não basta só que o museu seja acessível, a cidade tem que ser acessível' (Júlia).

Para que um espaço seja considerado um museu acessível não basta que, por exemplo, exista uma rampa ou um elevador, exposições com pavimentação adequada, alguns materiais táteis, se ao longo do trajeto ou se durante a visita houver obstáculos que não possam ser superados, ou transponíveis, ele perde a essência da inclusão, que é permitir que a pessoa faça parte daquele espaço em toda a sua plenitude e de maneira igualitária em todos os níveis. A existência de um único obstáculo pode comprometer todo o projeto de inclusão (COHEN; DUARTE; BRASILEIRO, 2012).

Assim, na categoria Acessibilidade programática ou institucional buscou-se identificar na fala dos entrevistados políticas, medidas e ações que buscassem diminuir ou sanar barreiras provenientes do museu como instituição pública, haja vista que estes têm a missão social de promover a diversidade, a igualdade e a emancipação dos visitantes, de tal forma que o ambiente possa ser usufruído por todos.

Sabe-se que a falta de recursos é um dos principais fatores apontados pelos gestores das instituições, observa-se no trecho extraído da fala da entrevistada Iasmim, coordenadora da Casa de Ciência e Cultura de Campo Grande:

Mas como é que eu vou fazer? Se eu tenho um vazamento, por exemplo, eu conserto aquilo ou faço uma rampa pra tornar a entrada acessível, entende? Falta recurso e não dá pra fazer tudo.

Até o ano passado a gente nem abria pra visitação (Iasmim).

O PNSM (BRASIL, 2010) estabelece como diretriz prioritária que haja recursos financeiros para que os museus realizem as adequações necessárias para que os espaços se tornem acessíveis, entretanto, essa não é a realidade observada, como constatado na fala da coordenadora. E essa realidade é recorrente nas falas dos entrevistados, ou seja, não é uma situação pontual e pode ser observada em:

Então, na verdade, a gente recebeu... em 2013, nós recebemos uma verba da pró-reitoria de cultura e extensão. Então, nós já colocamos questões visando à acessibilidade, né? Então, nós já investimos nessa área, quando nós construímos o museu. Foi o que nós fizemos dentro das condições financeiras que a gente tinha, né? Então, foi... o que deu pra fazer, nós fizemos (Andreia).

E também em:

Então, a gente tem toda essa preocupação, tá? Mas ainda é um processo, não posso dizerer ainda que somos acessiveis, né? Até porque também tem coisas que demandam investimento, né? [...] E por sermos vinculados à uma universidade, uma universidade do Estado, os recursos, eles não são assim, tão favoráveis, né? (Silmara).

É preciso garantir que as adaptações sejam viáveis financeiramente, para que os espaços museais se tornem acessíveis são necessárias então medidas complementares, dentre elas, financiamento para que as obras possam acontecer. O desenvolvimento de estratégias e adequações nos espaços culturais é um assunto que ainda gera desconforto e insegurança diante dos gestores desses espaços (SARRAF, 2013), e muitas dessas ações só foram realizadas a partir da obrigatoriedade imposta pela LBI 
(BRASIL, 2015) e isso pode ser observado pela fala da entrevistada do Guia, quando da sua constituição, a respeito da insegurança dos respondentes quanto aos itens de acessibilidade:

\begin{abstract}
Ainda mais sendo um tema tão delicado que os museus têm muito medo de se expor, porque ainda é um tema pouco trabalhado nos museus e muitos museus nem sabem que fazem ações de acessibilidade, de inclusão, né? Então... e também existe a questão das leis, né? Então, muitos museus, eles não queriam se expor, não queriam mostrar que têm poucas ações de acessibilidade (Júlia).
\end{abstract}

O público visitante é heterogêneo, então, além da falta de recursos para implantar recursos de acessibilidade, os museus enfrentam ainda a falta de capacitação específica para que os mediadores possam atender o público com deficiência adequadamente.

\title{
Então era a mediação sempre feita através da... da infraestrutura da própria escola. \\ E a gente tá, assim, a gente tá seguindo as... essa questão... porque assim, às vezes é sem querer e a gente faz coisas que excluem, né? (Iasmim).
}

A formação continuada dos monitores reflete a necessidade de aperfeiçoamento e a preocupação por parte dos gestores em superar um dos principais obstáculos da inclusão, que segundo Norberto Rocha e Marandino (2017), são justamente, a falta de preparo dos profissionais do campo museológico. A entrevistada relata:

\footnotetext{
Então, a gente tem um plano aqui de formação, mensalmente acontece uma palestra, acontece alguma atividade em que a gente tá investindo nessa questão, porque a acessibilidade, ela não passa só pelo estrutural, né? [...] inclusive, a última palestra que a gente teve, nós trouxemos um deficiente visual, e aí ele fez uma visitação, inclusive, testando esses materiais que a gente tem, né? E foi muito importante, assim, o relato dele, as dicas que ele deu pra gente de como falar com ele, de como se dirigir a ele, de como auxiliá-lo, que às vezes, a gente pensa que tá ajudando e não é daquela forma, né? (Silmara).
}

Sassaki (2009) aponta que a acessibilidade deve ser incorporada à prática, seja ela formal ou não formal, não devendo ficar restrita ao espaço físico e a dimensão estrutural da instituição, transpondo os obstáculos inerentes do processo de inclusão, para isso ressalta a importância de o público com deficiência participar das formações, com o objetivo de diminuir a distância entre o público e a exposição.

Ribeiro (2014) aponta que a mediação para a pessoa com deficiência pode ser considerada de difícil execução. Tal dificuldade se deve à falta de conhecimento sobre as formas de aquisição de conhecimento atrelado às necessidades de cada visitante. Dessa forma, o trabalho de mediação, por vezes, é reduzido à mera transmissão de informações em visitas demasiadamente longas, que primam pela ordem e silêncio, desconsiderando as especificidades desse público.

Nessa perspectiva, ressalta-se a necessidade de ampliar o conceito de mediação, compreendendo-a como uma ação compartilhada dos indivíduos com os mediadores. Nessa ação compartilhada o visitante se apropria dos conceitos científicos de forma lúdica e sensível (MENDES BRAGA, 2017).

Além de capacitar os profissionais dos museus e centros culturais, é necessário elaborar um diagnóstico referente às necessidades de cada museu (BRASIL, 2010), identificando prioridades de cada unidade museológica, para que isso possa ser feito de maneira que garanta e viabilize a interação público/museu, assim é necessário que a pessoa com deficiência faça parte da equipe que planeja e implementa essas ações. É fundamental que o museu tenha em sua equipe própria, a pessoa com deficiência atuando diretamente nas ações de acessibilidade, para apontar quais medidas estão realmente sendo acessíveis e promovendo a inclusão.

Segundo a entrevistada Amanda:

Tem, tem mediador com deficiência física. [...] ela está intimamente relacionada com isso e ajudando a gente pelo menos com essa parte da... da parte de deficiente físico pra gente poder melhorar os acessos (Amanda).

A Política Nacional de Educação Museal (BRASIL, 2018) define critérios para a superação das diversas barreiras que dificultam ou impedem o acesso aos museus e centros culturais e essas medidas não se restringem aos visitantes. É imprescindível, que a estruturação desses espaços atenda às 
necessidades de todos os seus usuários, garantindo respeito e plena fruição para todos, seguindo os ideais do Desenho Universal (ABNT, 2015). Entretanto, percebemos que muitas vezes o museu não está pronto para atender sequer seus profissionais, como exemplificado no excerto a seguir:

\footnotetext{
Atualmente não. Já tivemos, já tivemos e, na verdade, nessa época, a gente... nós tivemos problemas sim, porque o prédio nessa época não tinha, por exemplo, nenhum elevador... Então, ela acabou se transferindo pra um outro lugar, não que ela não desse conta, mas assim, ela preferiu mudar, acho que ela se sentia melhor. Pra um lugar mais adaptado pra ela, tá? Hoje, nós não temos, não, ninguém (Andreia).
}

Segundo Tojal (2007) as políticas museais necessitam de ações planejadas e de articulação a fim de preverem a acessibilidade de maneira integrada, tanto aos museus, quanto aos profissionais, minimizando a deficiência do espaço, que não está adaptado para atendê-los corretamente.

Aqui, em se tratando da relação à acessibilidade institucional apontamos que os MCA estão tomando providências que possibilitem o acesso da pessoa com deficiência, o que é um grande avanço para que esse público passe a participar efetivamente desses espaços. Porém, reafirmamos que a inclusão transpassa aspectos organizacionais, estruturais e políticos, portanto, é necessário que estas pessoas sejam incluídas desde o processo de planejamento e implementação dessas adaptações e mudanças nos museus de Ciências, visto que a percepção de atitudes e melhorias deve partir do público alvo. Também defendemos que os recursos de acessibilidade e as atividades de inclusão nos espaços museais beneficiariam a todos, visitantes e profissionais, não somente a pessoa com deficiência, assim como também apoia Sarraf (2013).

Na categoria Acessibilidade Comunicacional observou-se a existência/inexistência de equipamentos e recursos que permitam a superação ou, ao menos, minimização das barreiras comunicacionais, de escrita e/ou de informação, por meio da utilização de leitores de tela; tamanho da fonte; alternativas de idioma, por exemplo, LIBRAS ou BRAILLE, adaptação das exposições, criação de materiais táteis, manipuláveis e multissensoriais.

De acordo com Sarraf (2008, p. 38), “a acessibilidade é uma forma de concepção de ambientes que considera o uso de todos os indivíduos independente de suas limitações físicas e sensoriais, desenvolvida a partir dos conceitos do movimento de Inclusão Social". Vivenciar a inclusão não é uma tarefa fácil por parte dos museus, visto que não se trata apenas de reestruturações arquitetônicas no espaço, a inclusão requer mudanças efetivas sobre as possibilidades de receber cada pessoa.

A comunicação é uma necessidade básica e deve ser atendida nos espaços museais, assim como deve ser atendida nas demais esferas da sociedade. A acessibilidade comunicacional envolve toda forma de comunicação concebida para o espaço expositivo, incluindo a seleção dos objetos, textos, etiquetas, montagem e iluminação (TOJAL, 2007).

Segundo o Guia (NORBERTO ROCHA, et al., 2017), os museus participantes da pesquisa apresentam, em sua maioria, equipamentos podem ser manipulados por todos e materiais audiovisuais legendados em português. acessíveis é recente:

Percebemos na fala da entrevistada que a preocupação em criar ou tornar as exposições

Então, a gente não tinha essa tradição até agora [...] então são as constelações táteis que servem tanto pra cegos quanto pra espectro autista, pessoas com deficiência cerebral, né? Porque você concretiza, né? Então quem enxerga ou quem não enxerga vai poder tocar, vai, né? (Iasmim).

A acessibilidade comunicacional consiste na transformação de símbolos em outros meios para que as informações cheguem ao público sem que se percam suas características educacionais, sensoriais e possam acessadas por todas as pessoas independente de suas necessidades (FRANCO; SILVA, 2010). Entretanto, algumas exposições ainda não são acessíveis para todos os públicos, como evidenciado na fala a seguir:

Assim, dependendo da deficiência, né? Porque, por exemplo, a gente tem uma exposição muito... eu acho muito bonita que é de micrografias $3 D[. .$.$] então esse daí não tem sentido pra cegos, por exemplo (Iasmim).$ 
Os Museus de Ciências estão se adaptando à acessibilidade e a inclusão da pessoa com deficiência, preparando materiais e adequando as exposições, entretanto, essas mudanças envolvem mais do que sujeitos, objetos e conhecimentos, é preciso que as exposições sejam configuradas de maneira adequada para que os educadores e os visitantes possam interagir durante a visita (SARRAF, 2008). Assim,

Nas nossas exposições... nas nossas exposições a gente faz uma leitura de diferentes experimentos, tá certo? Pra que as pessoas possam perceber. Por exemplo, você faz experimento de quente e frio mostrando a lei da termodinâmica, né? (Osvaldo).

Para Santaella (2005), nossas sensações não são controladas por receptores mecanizados, mas por um conjunto de sensações e pela sobreposição dos sentidos, portanto, em concordância com Tojal (2015), as medidas de acessibilidade não devem ser oferecidas de maneira isolada. É certo que a percepção humana se dá por meio da combinação de estímulos e das sensações por eles produzidas, porém, mais que a soma dessas sensações, é necessário levar em conta que nem sempre os recursos disponíveis alcançarão seu propósito se não planejados em conjunto com seus receptores.

Durante a entrevista, notamos a relevância da utilização de novos meios de comunicação na fala da entrevistada:

Por exemplo, nós temos aqui, lá na química, um modelo atômico, né? Que é uma placa de metal e aí tem as pecinhas que são os prótons, os elétrons, [...] quando chegou lá, eles ficavam, assim, muito encantados, né? Em perceber, por exemplo, ver... ver, né? Como é um átomo, né? Que só tinham ouvido falar, as pessoas descrevem, mas assim, o tocar, o sentir a materialidade das coisas, né? (Silmara).

A importância e a relação da linguagem e da arte na formação do sujeito crítico e participativo são claras e notórias e não podem ser negadas à pessoa com deficiência. Portanto, os recursos comunicativos precisam valorizar e aproveitar as condições disponíveis para se tornarem cada vez mais significativos.

Os museus de Ciências têm enfrentado muitas dificuldades para tornar seus espaços não somente acessíveis, mas também inclusivos. Dentre essas, nota-se que a mais citada durante as entrevistas, é a dificuldade em adequar as exposições, garantindo que o visitante com deficiência possa usufruir de todo o espaço museal, por exemplo:

Acho que um grande desafio, talvez, seja a cúpula em sim, né? Porque tem a dificuldade do visual, que não vai conseguir
visualizar a imagem, a pessoa aqui, já fez o contato, há uma expectativa, uma intenção de se fažer sessões áudio-descritivas,
né? E o auditivo também tem dificuldade na cúpula, porque ele vê a imagem, mas ele não escuta a narração, aí
a gente pensa em fazer sessóes também com tradução em LIBRAS (Silmara).

De acordo com as definições da Norma Brasileira Regulamentadora (NBR) 9050 (ABNT, 2015) deve haver um local determinado para o posicionamento do intérprete de LIBRAS e deve ser garantido um foco de luz posicionado de forma a iluminar o intérprete de sinais, desde a cabeça até os joelhos, entretanto, essa determinação, que garante a qualidade da interpretação, prejudica, por exemplo, as sessões na cúpula do planetário. A proposta é que cada instituição se adeque para receber a pessoa com deficiência, mas, a preocupação reside em como essa comunicação será estabelecida.

Assim, os recursos devem se voltar para satisfazer as exigências do espaço, da acessibilidade e do visitante, sem essa preocupação, não irão ter êxito em sua função, e devem ser acompanhados da acessibilidade atitudinal, permitindo o manejo de forma adequada, viabilizando sua implantação efetiva e de maneira eficaz (TOJAL, 2015).

A inclusão envolve um processo de reforma, não somente das estruturas e sistemas, mas de comportamento. É necessário incorporar as modificações no conteúdo, nos métodos, nas abordagens, nas estratégias de educação para superar barreiras, buscando oferecer a todos uma experiência e um ambiente de aprendizado igualitário e participativo, que corresponde às suas demandas. Inserir a pessoa com deficiência em espaços sem esses aprimoramentos e modificações não constitui inclusão (CARDINALI, 2008). 
A autora destaca também, que a acessibilidade comunicacional está diretamente associada à acessibilidade atitudinal, enfatizando que é necessário pensar nos processos de comunicação museológica de maneira que privilegiem todas as formas de mediação buscando garantir a eficácia no atendimento à pessoa com deficiência. Assim, na categoria Acessibilidade Atitudinal foram observadas as ações voltadas a eliminar os preconceitos, estereótipos e estigmas existentes entre as pessoas nos espaços museais observados, buscando localizar atitudes que promovem práticas e intervenções inclusivas.

Foi possível observar, então, que as instituições têm desenvolvido práticas de sensibilização e de conscientização, muitas vezes de forma espontânea, o que resulta na quebra de preconceitos, estigmas, estereótipos e discriminações, como em:

A acessibilidade, ela também é atitudinal, então, eu posso ter os equipamentos, posso ter alguma estrutura, mas eu preciso de ter pessoas que consigam compreender como elas lidam com essas pessoas, com esses visitantes, isso desperta, sensibiliza a gente e gera essa preocupação em melhor atendê-los (Silmara).

A acessibilidade atitudinal é considerada a chave fundamental, e talvez, a mais presente nos museus de Ciências, para garantir que as necessidades dos visitantes sejam atendidas e respeitadas, pois, sensibiliza e tira o foco da deficiência, ampliando o olhar para a pessoa (TOJAL, 2015), como em:

É um.. é um verdadeiro... alegria pra todo mundo quando eles chegam lá, e é impressionante, eles saem do laboratório com muita... que o laboratório ele é interativo, é proibido não mexer, então eles ficam contato em tudo, né? É isso que é a nossa função que eu acho importante (Osvaldo).

Desta forma, entendemos que mais do que a missão das instituições, a acessibilidade atitudinal provoca e desperta o sentimento de respeito ao próximo, estimulando práticas e ações educativas inclusivas, que são benéficas para os dois lados, o dos mediadores e dos visitantes, o que enriquece ainda mais a experiência e a aprendizagem provocada nos Museus de Ciências (SASSAKI, 2009), e também pode ser observado em:

E é uma coisa que tá empolgando muito os nossos alunos, nossos monitores (Iasmim).

Para Ponte e Silva (2015), as barreiras atitudinais impedem e/ou dificultam a inclusão da pessoa com deficiência e as atitudes da sociedade podem ser facilitadoras desse processo, pois integram o sujeito e a sociedade. As práticas museais devem valorizar a diversidade, estimular o respeito pelas diferenças, acolher e participar do processo de inclusão. O conhecimento e a fruição presente nos museus, espaços científico-culturais e ações de divulgação científica, devem contemplar todas as audiências, sem distinções.

A inclusão apresenta como aliada a acessibilidade. Ambas não se restringem apenas à exclusão de barreiras físicas, mas também, a inclusão sociocultural, que não depende somente das condições físicas do sujeito, pois, ser incluído e ter acesso a algo e/ou a alguém é direito de todas as pessoas com ou sem deficiências e não acontecem somente com a eliminação de obstáculos, e sim, com a criação de novos elos.

O impedimento atitudinal não é tão visível quanto o físico e, na maioria das vezes, é inconsciente, e de difícil reconhecimento por parte de quem o pratica. Pereira et al. (2011, p. 301) apresentam uma reflexão diante da falta de acessibilidade atitudinal, que "leva as pessoas com deficiência a se sentirem à margem da sociedade, o que gera, muitas vezes, perturbações de estima e comportamento, o que contribui ainda mais para a segregação social".

A inclusão preconiza a valorização das diferenças, a igualdade, a cooperação, a solidariedade e o direito a todos de usufruírem com qualidade de todos os aspectos da vida, tais como: lazer, cultura, trabalho e educação, mas, apesar dos avanços, as políticas públicas ainda necessitam de uma melhor normatização para garantir a efetivação desses direitos.

Considerando o exposto, buscamos apresentar, como relato de uma experiência museal acessível, a visita ao Museu de Ciências Catavento Cultural e Educacional ${ }^{3}$ de São Paulo que se destaca

${ }^{3}$ Disponível em: https://museucatavento.org.br/

Educação em Revista|Belo Horizonte|v.36|e234507|2020 
por possuir ações de acessibilidade e um departamento específico para a execução das mesmas, o Núcleo de Acessibilidade, bem como, cursos de formação aos profissionais do espaço, tendo em vista o aprimoramento das práticas inclusivas.

As ações educativas inclusivas do museu em questão podem acontecer em visitas agendadas ou durante a visitação espontânea, entretanto, quando o agendamento é feito, um mediador preparado acompanha o visitante durante todo o percurso.

Há uma rota acessível para o visitante, que contempla todas as seções do museu, porém se concentra, principalmente, no piso térreo, com o objetivo de tornar mais fácil a locomoção quando se trata de uma visitação espontânea. A maior parte do trajeto contém piso tátil para que o visitante com deficiência visual possa se locomover de maneira autônoma e segura.

A exposição Biomas do Brasil é considerada pelos mediadores e coordenadores de acessibilidade, a mais acessível do museu, pois foi concebida com essa finalidade e não adaptada, posteriormente, para atender o público depois de sua construção. Ela possui um mapa tátil que indica tudo que será abordado nessa seção, além disso, as informações escritas em português estão transcritas em Braille, em Libras, e possuem audiodescrição.

Os mapas dos biomas possuem relevos e texturas que os caracterizam em cada região, todas as bancadas estão em altura acessível para cadeirantes ou pessoas de baixa estatura e podem ser tocadas, entretanto, somente, pelo público deficiente visual. Apesar de ser e estar acessível ao público, em todos os painéis táteis há essa observação: "apenas para deficientes visuais". Ao ser questionado sobre isso, o departamento de acessibilidade disse que essa é uma medida tomada para preservação do acervo, já que número de visitantes diários é alto e as peças sofrem deterioração devido ao manejo, e os custos para manutenção e reposição são elevados.

Entendemos que a conservação da exposição é um dos problemas apontados pelos coordenadores dos museus de Ciências, por possuírem um caráter mais interativo e menos contemplativo, entretanto, as práticas inclusivas contribuem para o aprendizado (MARANDINO, 2009) e devem estar ao alcance e disponíveis para todos os visitantes, e os custos para a manutenção devem constar nos planejamentos anuais. As práticas inclusivas não devem, em nenhum momento, serem segregativas (SASSAKI, 2009), portanto, salientamos a importância desse movimento de inclusão acontecer de maneira universal e sem restrições.

Para auxiliar no processo de inclusão da pessoa com deficiência nessa esfera, o Catavento ainda conta com dois carrinhos acessíveis, um para a seção Vida e outro para a seção Astronomia. Esses carrinhos foram criados na intenção do visitante poder tocar em objetos que se assemelhem aos itens da exposição e que não podem ser manipulados.

Os carrinhos acessíveis, atualmente, não atendem somente ao museu, eles têm sido levados às escolas, cursos de formação de professores e cursos de formação de mediadores. O objetivo é que cada seção possa ter seu próprio carrinho acessível no futuro, para que os recursos estejam disponíveis durante toda a permanência do público no espaço museal.

Durante a visita ao Catavento Cultural e Educacional, fica clara a imensa necessidade que os museus têm de obter recursos para que as medidas de acessibilidade sejam implantadas. De fato, é imprescindível que o público possa ter acesso a esses locais e os avanços nessa questão já são visíveis, porém, as estratégias inclusivas ainda são pontuais, específicas, fragmentadas e segregativas.

Há tempos, o espaço museal deixou de ser um ambiente nostálgico, predominantemente de contemplação e passou a ser um lugar interativo, vivo e participativo, para que os visitantes se sintam acolhidos ao chegar ao museu é fundamental que haja mediadores para recebê-los e tornar essa visita agradável e educativa.

Ações de acessibilidade física, auditiva, visual e intelectual são direitos garantidos por Lei e cada vez mais devem estar presentes em todos os âmbitos sociais e culturais, dentre eles, o museu, entretanto, o que se observa é que a medida de acessibilidade mais presente ainda é a acessibilidade atitudinal, que como o próprio nome diz, é intrínseca ao ato, ao movimento, à atitude. Atitude essa de incluir, que é natural ao ser humano, que transpassa e vai além das teorias. Ela é a prática, a prática de tornar possível, de tornar acessível, de fazer com que a inclusão aconteça e muitas vezes ela ultrapassa 
barreiras arquitetônicas, estruturais, barreiras de comunicação, entretanto, não pode ser a grande responsável para que a inclusão aconteça.

\section{CONSIDERAÇÕES FINAIS}

Buscando responder o objetivo dessa pesquisa: quais dimensões da Educação Inclusiva estão presentes/ausentes nos Museus de Ciências brasileiros, por meio da fundamentação teórica apresentada e das entrevistas realizadas com os diretores e/ou coordenadores das instituições museais é possível fazer alguns apontamentos quanto à inclusão e acessibilidade nos Museus de Ciências.

As dimensões observadas foram: dimensão física, dimensão programática, dimensão comunicacional e dimensão atitudinal, e ao buscarmos entender como e se elas estão presentes nos espaços percebemos que algumas medidas ainda estão disponíveis com restrições, mesmo no museu que utilizamos como exemplo de ações acessíveis.

Ao observarmos a dimensão física, sinalizamos que os espaços museais ainda possuem muitas barreiras físicas e arquitetônicas, alguns prédios são tombados como patrimônio e não podem passar por alterações tão facilmente, assim, além de prejudicarem o acesso às instituições, impossibilitam que as pessoas com dificuldade de locomoção acessem os ambientes. Essa dimensão está totalmente presente apenas no Laboratório de Divulgação Científica Ilha da Ciência, disponível com restrições no Centro de Ciências e Planetário do Pará e no Catavento Cultural e Educacional e disponível de maneira segregada na Casa de Ciência e Cultura de Campo Grande e no Museu Dinâmico Interdisciplinar.

Ao analisarmos a dimensão programática, foram identificadas ações que buscam diminuir as barreiras provenientes da falta de formação dos mediadores para que possam atender a heterogeneidade do público adequadamente. Esta dimensão está totalmente presente nos museus Museu Dinâmico Interdisciplinar e Catavento Cultural e Educacional, destacamos aqui, a criação do Núcleo de Acessibilidade por parte do museu Catavento, voltado à discussão de estratégias e implementação de medidas voltadas à inclusão e acessibilidade no espaço. A dimensão programática está disponível com restrições na Casa da Ciência e Cultura de Campo Grande e no Centro de Ciências e Planetário do Pará e está ausente no Centro de Divulgação Científica e Cultural da USP.

Os museus têm buscado estabelecer ações de articulação e potencialização para promover a inclusão de maneira íntegra, tanto aos espaços, quanto aos profissionais. Observamos que a formação continuada dos monitores é uma das preocupações dos gestores para superar a falta de preparo ao atender os variados tipos de público, entretanto, as medidas ainda são pontuais e inespecíficas, salientamos que é imprescindível que rompamos com regulamentos, atitudes e políticas que perpetuam a exclusão de forma explícita ou velada.

$\mathrm{Na}$ dimensão comunicacional, foram localizadas exposições que contém alternativas de idioma, por exemplo, LIBRAS ou BRAILLE, e, principalmente, a criação de materiais táteis, manipuláveis e multissensoriais. Foi possível constatar que essa proposta não está disponível em todos os Museus, entretanto, está disponível com restrições na Casa da Ciência e Cultura de Campo Grande, Laboratório de Divulgação Científica Ilha da Ciência e no Catavento Cultural e Educacional, disponível de maneira segregada no Centro de Ciências e Planetário do Pará e no Museu Dinâmico Interdisciplinar e ausente no Centro de Divulgação Científica e Cultural da USP.

As análises apontam que essas mudanças envolvem mais do que a variação linguística, é preciso que as exposições sejam configuradas de maneira adequada para que os educadores e os visitantes possam interagir durante a visita, ou seja, é necessário analisar se os recursos audiovisuais estão favorecendo a aprendizagem, ou se estão apenas legendando as exposições (TOJAL, 2015). A grande maioria também, não está disponível para todo e qualquer tipo de público, sendo destinada apenas ao público não vidente ou ao público com deficiência intelectual, por exemplo.

Essa prática não promove a inclusão, apesar de criar um novo meio de comunicação, uma forma mais acessível, continua, entretanto, enfatizando ações que segregam, separam e que excluem.

Nos aspectos da dimensão atitudinal, foi possível observar que as instituições têm desenvolvido práticas de sensibilização e de conscientização, muitas vezes de forma espontânea, o que resulta na quebra de preconceitos, estigmas, estereótipos e discriminações, o que a faz ser a dimensão 
mais presente dentre as que listamos aqui. Ela está totalmente disponível em quatro das seis instituições que fazem parte dessa pesquisa, dentre elas, a Casa da Ciência e Cultura de Campo Grande, o Laboratório de Divulgação Científica Ilha da Ciência, o Museu Dinâmico Interdisciplinar e o Catavento Cultural e Educacional, nas outras duas instituições ela está disponível com restrições - Centro de Ciências e Planetário do Pará e Centro de Divulgação Científica e Cultural da USP.

Essa dimensão é considerada chave fundamental para a inclusão, pois está diretamente relacionada ao contato direto com o visitante, tirando o foco da deficiência e ampliando o seu olhar para o todo, entretanto, isoladamente, ela não pode ser a grande responsável pela inclusão.

Diante do exposto nesse trabalho, é possível concluir que os museus têm se adaptado para receber o público com deficiência, entretanto, as informações autodeclaradas no Guia não correspondem fielmente à realidade das instituições segundo a fala dos entrevistados, assim, concluímos que a visitação in loco é o melhor instrumento para identificar as medidas de acessibilidade. A discrepância das informações reitera a insegurança dos coordenadores quando questionados sobre as ações de acessibilidade, visto que essas estão garantidas em Lei e ainda não estão sendo colocadas em prática, o que demonstra uma preocupação tardia e muitas vezes, ineficaz. Enfatizamos ainda, que os recursos destinados à acessibilidade devem ser empregados para que essa adaptação ocorra e não devem ser utilizados para suprir as necessidades nos demais setores.

Destacamos que as ações desenvolvidas no museu Catavento Cultural e Educacional podem ser tomadas como referência nesse movimento. Salientamos que a inclusão não é um processo pontual, ao contrário, é um movimento progressivo e deve ser pautado em medidas tangíveis, inclusive, de fácil manutenção para que possam estar, efetivamente, disponíveis para todos os públicos. A implementação dessas mudanças deve ocorrer a curto, médio e longo prazo, visto que não é possível sanar definitivamente, todas as necessidades dos espaços e/ou dos seus visitantes.

Entendemos que as práticas museais devem valorizar a diversidade, estimular o respeito, acolher e incluir. Além disso, é fundamental que estejam disponíveis para todos os públicos, sem distinções, e cabe a cada instituição dedicar-se a desenvolver ações e melhorias da melhor maneira possível para que a acessibilidade contribua significativamente para a inclusão.

Sinalizamos que a inclusão é um processo, felizmente, irreversível e que não pode ser sufocado, uma vez que, quando a mínima medida é tomada ela se perpetuará. Reconhecemos que mais do que a divulgação científica, as instituições museais devem promover a acessibilidade de tal forma, que essa provoque e desperte o sentimento de respeito ao próximo, estimulando práticas e ações que efetivamente incluam o público visitante, enriquecendo ainda mais o encantamento, a experiência e a aprendizagem nos museus de Ciências.

Ressaltamos ainda a necessidade de que as pesquisas futuras se dediquem a entender como e se a inclusão realmente é efetiva, busquem incluir a pessoa com deficiência desde o processo de pesquisa até o final desse movimento, onde o público é incluído, proporcionando o diálogo e reafirmando as políticas de inclusão.

\section{AGRADECIMENTOS}

O presente trabalho foi realizado com apoio da Coordenação de Aperfeiçoamento de Pessoal de Nível Superior - Brasil (CAPES) - Código de Financiamento 001. Ao Museu Catavento Cultural e Educacional pela participação na pesquisa.

\section{REFERÊNCIAS}

AIDAR, G. Museus e inclusão social. Ciências \& Letras, Porto Alegre: Faculdade Porto-Alegrense de Educação, Ciências e Letras, n. 31, p. 53-62, 2002.

ASSOCIAÇÃO BRASILEIRA DE NORMAS TÉCNICAS (ABNT). NBR 9050: acessibilidade a edificações, mobiliário, espaços e equipamentos urbanos. Rio de Janeiro, 2015. Disponível em: <https://www.ufpb.br/cia/contents/manuais/abnt-nbr9050-edicao-2015.pdf>. Acesso em: 03 dez. 2018. 
BARDIN L. Análise de conteúdo. 3. ed. Lisboa: Edições 70, 2016.

BRASIL. Lei no 13.146, de 06 de julho de 2015. Institui a Lei Brasileira de Inclusão da Pessoa com Deficiência (Estatuto da Pessoa com Deficiência). Diário Oficial da União, Brasília, DF, 2015, 06 jul. Seção 1, p. 1. Disponível em: <http://www.planalto.gov.br/ccivil_03/_Ato2015-

2018/2015/Lei/L13146.htm>. Acesso em: 13 jan. 2019.

BRASIL. Ministério da Cultura. Instituto Brasileiro de Museus. Plano Nacional Setorial de Museus - 2010/2020. Ministério da Cultura: Brasília, 2010. Disponível em: <http://www.museus.gov.br/wpcontent/uploads/2012/03/PSNM-Versao-Web.pdf>. Acesso em: 12 fev. 2019.

BRASIL. Ministério da Cultura. Instituto Brasileiro de Museus. Caderno da Política Nacional de Educação Museal. Ministério da Cultura: Brasília, 2018. Disponível em:

<https://www.museus.gov.br/wp-content/uploads/2018/06/Caderno-da-PNEM.pdf>. Acesso em: 15 fev. 2019.

CARDINALI, S. M. M. O Ensino e Aprendizagem da Célula em Modelos Táteis para Alunos Cegos em Espaços de Educação Formal e Não Formal. 2008. 109f. Dissertação (Mestrado em Ensino de Biologia) - programa de Pós-Graduação em Ensino de Ciências e Matemática, Pontifícia Universidade Católica de Minas Gerais, Minas Gerais, 2008. Disponível em:

<http://www.biblioteca.pucminas.br/teses/EnCiMat_CardinaliSM_1.pdf>. Acesso em: 29 out. 2018.

CAZELLI, S.; MARANDINO, M.; STUDART, D. Educação e comunicação em museus de ciência: aspectos históricos, pesquisa e prática. In: MARANDINO, M. Educação e museu: a construção social do caráter educativo dos museus de ciências. Rio de Janeiro. Rio de Janeiro: Access Editora, 2003. p. 83-106. Disponível em:

<https://edisciplinas.usp.br/pluginfile.php/844165/mod_resource/content/1/CAZELLI_MARAN DINO_STUDART_Educa $\% \mathrm{C} 3 \% \mathrm{~A} 7 \% \mathrm{C} 3 \% \mathrm{~A} 3 \mathrm{O} \_\% 20 \mathrm{Comunica} \% \mathrm{C} 3 \% \mathrm{~A} 7 \% \mathrm{C} 3 \% \mathrm{~A} 3 \mathrm{o}$ _em_Museus_d e_Ci\%C3\%AAncia.pdf>. Acesso em: 14 dez. 2018.

CERATI, T. M. Educação em jardins botânicos na perspectiva da alfabetização científica: análise de uma exposição e público. 2014. 240 f. Tese (Doutorado em Educação) - Faculdade de Educação, Universidade de São Paulo, São Paulo, 2014. Disponível em:

<http:/ /www.teses.usp.br/teses/disponiveis/48/48134/tde-02042015-114915/pt-br.php>. Acesso em: 22 dez. 2018.

COHEN, R.; DUARTE, C.; BRASILEIRO, A. Acessibilidade a Museus: Cadernos Museológicos, Brasília: MinC/IBRAM, 2012. Disponível em: <http://www.museus.gov.br/wpcontent/uploads/2013/07/acessibilidade_a_museu_miolo.pdf>. Acesso em: 04 ago. 2018.

DITTRICH, M. G.; LEOPARDI, M. T. Hermenêutica fenomenológica: um método de compreensão das vivências com pessoas. Discursos fotográficos, Londrina, v.11, n.18, p.97-117, jan./jun. 2015.

Disponível em:

<www.uel.br/revistas/uel/index.php/discursosfotograficos/article/download/.../16814>. Acesso em: 12 abr. 2019.

FLICK, U. Introdução à pesquisa qualitativa. 3.ed. Porto Alegre: Artmed editora, 2008.

FRANCO, E. P. C.; SILVA, M. C. C. C. da. Audiodescrição: breve passeio histórico. In: MOTTA, L. M. V. de M.; ROMEU FILHO, P. Audiodescrição: transformando imagens em palavras, São Paulo: Secretaria dos Direitos da Pessoa com Deficiência do Estado de São Paulo, 2010, p. 23-42.

GIL, A. C. Métodos e técnicas de pesquisa social. 6. ed. São Paulo: Atlas SA, 2008.

INACIO, L. G. B. Indicadores do potencial de acessibilidade em Museus e Centros de Ciências: análise da Caravana da Ciência. 104 f. Trabalho de conclusão de curso (Ensino de Ciências com ênfase em Biologia e Química) - Instituto Federal de Educação, Ciência e Tecnologia do 
Rio de Janeiro, Rio de Janeiro, 2017. Disponível em: < https://grupomccac.org/indicadores-dopotencial-de-acessibilidade-em-museus/>. Acesso em: 11 fev. 2019.

JACOBUCCI, D. F. C. Contribuições dos espaços não-formais de educação para a formação da cultura científica. Em extensão, Uberlândia, v. 7, n. 1, jan. 2008. Disponível em:

<http://www.seer.ufu.br/index.php/revextensao/article/view/20390>. Acesso em: 04 nov. 2018.

MARANDINO, M. A biologia nos museus de ciências: a questão dos textos em

bioexposições. Ciência \& Educação, Bauru, v. 8, n. 2, p. 187-202, mar. 2002. Disponível em:

< http://www.scielo.br/pdf/ciedu/v8n2/04.pdf>. Acesso em: 30 out. 2018.

MARANDINO, M. Museus de ciências como espaços de educação. In: FIGUEREDO, B. G.; VIDAL, D. G. Museus: dos gabinetes de curiosidades à museologia moderna. Belo Horizonte: Argumentum, p. 165-176, 2005. Disponível em:

$<$ https://edisciplinas.usp.br/pluginfile.php/844082/mod_resource/content/2/MARANDINO_Muse us_de_Ci $\%$ C3\%AAncias_como_espa $\%$ C3\%A7os_de_educa $\%$ C $3 \%$ A 7\%C3\%A3o.pdf $>$. Acesso em: 11 jan. 2019.

MARANDINO, M. Museus de Ciências, Coleções e Educação: relações necessárias. Museologia e Patrimônio, Rio de Janeiro, v. 2, n. 2, p. 1-12, fev. 2009. Disponível em:

<http://www.geenf.fe.usp.br/v2/wp-content/uploads/2012/10/museologia_marandino2009.pdf>. Acesso em: 12 jan. 2019.

MARQUES, L. P.; MARQUES, C. A. Dialogando com Paulo Freire e Vygotsky sobre educação. In: REUNIÃO ANUAL DA ASSOCIAÇÃO NACIONAL DE PÓS-GRADUAÇÃO E PESQUISA EM EDUCAÇÃO, 29., 2006. Rio de Janeiro. Anais... Rio de Janeiro: ANPED, 2006, p. 1-14. Disponível em: <http://www.anped.org.br/biblioteca/item/dialogando-com-paulo-freire-e-vygotsky-sobreeducacao >. Acesso em: 06 out. 2018.

MASSARANI, L. et al. Aproximaciones a la investigación en divulgación de la ciencia en América Latina a partir de sus artículos académicos. Rio de Janeiro: Fiocruz - COC, 2017. Disponível em: <http://www.redpop.org/wp-content/uploads/2015/06/Aproximaciones-a-lainvestigaci $\% \mathrm{C} 3 \% \mathrm{~B} 3 n$-en-divulgaci $\% \mathrm{C} 3 \% \mathrm{~B} 3$ n-de-la-ciencia-en-Am $\% \mathrm{C} 3 \% \mathrm{~A} 9$ rica-Latina-a-partir-desus-art\%C3\%ADculos-acad\%C3\%A9micos.pdf>. Acesso em: 17 mar. 2019.

MENDES BRAGA, J. Desafios e Perspectivas para Educação Museal. Museologia \& Interdisciplinaridade, Brasília, v. 6, n. 12, p. 55-64, set. 2017. Disponível em: $<$ http://periodicos.unb.br/ojs248/index.php/museologia/article/view/23288>. Acesso em: $01 \mathrm{fev}$. 2019.

MOLENZANI, A. O.; NORBERTO ROCHA, J. Acessibilidade nos museus e centros de ciências da cidade de São Paulo. Revista do Encontro de Divulgação de Ciência e Cultura, Campinas, v. 3, n. 3, p. 71-83, abr. 2017. Disponível em:

<http://revistas.iel.unicamp.br/index.php/edicc/article/view/5219>. Acesso em: 18 jan. 2019.

NORBERTO ROCHA, J. et al. Museus e Centros de Ciências Acessíveis da América Latina e do Caribe Rio de Janeiro: RedPOP; Montevidéu: Unesco, 2017. Disponível em: < http://www.redpop.org/wp-content/uploads/2017/12/GUIA-PT-Final_semaudiodescri\%C3\%A7\%C3\%A3o.pdf>. Acesso em: 16 jun. 2018.

NORBERTO ROCHA, J.; MARANDINO, M. Museus e centros de ciências itinerantes: possibilidades e desafios da divulgação científica. Revista do Encontro de Divulgação de Ciência e Cultura, Campinas, v. 3, n. 3, p. 49-58, abr. 2017. Disponível em: <https://canalcederj.cecierj.edu.br/092017/7a06de091ef9208d7684c969de1ce22b.pdf>. Acesso em: 14 fev. 2019. 
OLIVEIRA, G. O museu como um instrumento de reflexão social. Museus e Estudos

Interdisciplinares, Portugal, v. 2, n. 1, p. 222-235, abr. 2013. Disponível em:

<https://www.academia.edu/3588318/o_museu_como_um_instrumento_de_reflex\%C3\%A3o_social _the_museum_as_a_social_reflection_tool_by_genoveva_oliveira $>$. Acesso em: 02 mar. 2019.

PEREIRA, L. M. F; CARIBÉ, D., GUIMARÃES, P., MATSUDA, D. Acessibilidade e crianças com paralisia cerebral: a visão do cuidador primário. Fisioterapia em Movimento, Curitiba, v. 24, n. 2, p. 299-306, 2011. Disponível em: < http://www.scielo.br/pdf/fm/v24n2/a11v24n2.pdf>. Acesso em: 29 jul. 2019.

PONTE, A. S.; SILVA, L. C. A acessibilidade atitudinal e a percepção das pessoas com e sem deficiência. Cadernos Brasileiros de Terapia Ocupacional, UFSCar, São Carlos, v. 23, n. 2, p. 261 271, jul. 2015. Disponível em: <http://doi.editoracubo.com.br/10.4322/0104-4931.ctoAO0501>. Acesso em: 13 out. 2019.

RIBEIRO, G. G. A mediação museológica: formação de mediadores para promoção de acessibilidade universal no Museu Nacional. 92 f. Trabalho de Conclusão de Curso (Especialização em Acessibilidade Cultural) - Universidade Federal do Rio de Janeiro, Rio de Janeiro, 2014. Disponível em: <http://www.repositorio-

bc.unirio.br:8080/xmlui/bitstream/handle/unirio/11768/Disserta\%C3\%A7\%C3\%A3o\%20PPGEdu $\% 20-\% 20$ Guilhermina\%20Guabiraba.pdf?sequence=1\&isAllowed $=\mathrm{y}>$. Acesso em: 17 ago. 2019.

RODRIGUES, D. A Inclusão na Universidade: limites e possibilidades da construção de uma Universidade Inclusiva. Revista Educação Especial, Santa Maria, v. 1, n. 23, p. 9-15, mar. 2012. Disponível em: <https://periodicos.ufsm.br/educacaoespecial/article/view/4951>. Acesso em: $08 \mathrm{de}$ nov. 2018.

SANTAELLA, L. Matrizes da linguagem e pensamento: sonora, visual, verbal. Aplicações na hipermídia. São Paulo, Iluminuras/Fapesp, 2005.

SARRAF, V. P. Reabilitação do museu: políticas de inclusão cultural por meio da acessibilidade. 2008. 181 f. Dissertação (Mestrado em Cultura e Informação) - Escola de Comunicações e Artes, Universidade de São Paulo, São Paulo, 2008. Disponível em: <

www.teses.usp.br/teses/disponiveis/27/27151/tde-17112008.../reabilitacaomuseu.pdf $>$. Acesso em: 30 ago. 2018.

SARRAF, V. P. A comunicação dos sentidos nos espaços culturais brasileiros: estratégias de mediações e acessibilidade para as pessoas com suas diferenças. 2013. $251 \mathrm{f}$. Tese (Doutorado em Comunicação e Semiótica) - Programa de Pós-graduação em Comunicações e Semiótica, Pontifícia Universidade Católica de São Paulo, São Paulo, 2013. Disponível em:

<http://www.museusacessiveis.com.br/arquivosDown/20140326143526_tesedigital.pdf>. Acesso em: 04 de jan. 2019.

SASSAKI, R. K. Inclusão: acessibilidade no lazer, trabalho e educação. Revista Nacional de Reabilitação, São Paulo, v. 11, p. 10-16, mar./abr. 2009. Disponível em: <https://acessibilidade.ufg.br/up/211/o/SASSAKI_-_Acessibilidade.pdf?1473203319>. Acesso em: 10 de abr. 2019.

SASSAKI, R. K. Inclusão: o paradigma do século 21. Revista da Educação Especial, Santa Maria, v. 31, n. 60, p. 19-23, out. 2005. Disponível em:

$<$ https://periodicos.franca.unesp.br/index.php/caminhos/article/viewFile/64/59>. Acesso em: 09 de jan. 2019.

TOJAL, A. P. da F. Museu de Arte e Público Especial. 1999. 200f. Dissertação (Mestrado em Artes) - Escola de Comunicações e Artes, Universidade de São Paulo, São Paulo, 1999. Disponível em: < http://arteinclusao.com.br/publicacoes-artigos/ >. Acesso em: 15 jul. 2018. 
TOJAL, A. P. da F. Políticas Públicas Culturais de Inclusão de Públicos Especiais em Museus. 2007. 322 f. Tese (Doutorado em Ciência da Informação) - Escola de Comunicações e Artes, Universidade de São Paulo, São Paulo, 2007. Disponível em: <

http://arteinclusao.com.br/publicacoes-artigos/ >. Acesso em 03 jun. 2018.

TOJAL, A. Política de acessibilidade comunicacional em museus. Museologia \&

Interdisciplinaridade, Brasília, v. 4, n. 7, p. 190-202, nov. 2015. Disponível em:

<http://periodicos.unb.br/index.php/museologia/article/viewFile/16629/11864>. Acesso em: 05 jan. 2019.

Submetido: $28 / 02 / 2020$

Aprovado: $22 / 05 / 2020$ 